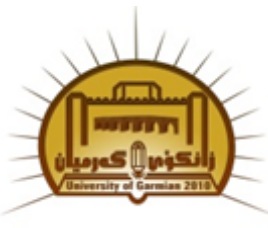

Available online at http://jgu.garmian.edu.krd

Journal of Uni versity of Garmian

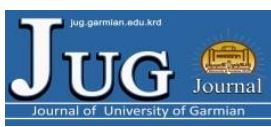

https://doi.org/10.24271/garmian.196351

\title{
The Contrasting Worlds of Ursula K. Le Guin's Always Coming Home: An Ecofeminist Study
}

\author{
Danaz Abubaker Abdullah, Azad Hamad Sharif
}

Department of English, College of Languages, Sallahaddin University

\section{Article Info}

Received: July, 2019

Revised:August,2019

Accepted:August,2019

\section{Keywords}

Ecofeminism, Alternative World, oppression, Kesh, Condor

Corresponding Author

drazadsharif@gmail.com

\begin{abstract}
This study analyses from an ecofeminist perspective the contrasting worlds of the feminist character in Ursula K. Le Guin's most prominent novel Always Coming Home (1985) (abbreviated as ACH). The central subject of the novel focuses on oppressed women and nature as inferior to men and how they are dominated in patriarchal Condor. It also examines the interrelatedness of both women and nature through the experiences of the heroine, Stone Telling in two different worlds of Kesh and Condor. Additionally, it presents profound ecological consciousness of Kesh society and the severe deterioration and exploitation of Condor society. This research displays the concerns of ecology and feminism in relation to equality because by equality nature will be protected through the participation of both genders. The study sums up the conclusion that through the partnership of both genders humans and nature will be protected from any future deterioration.
\end{abstract}

\section{Introduction}

This chapter explores the ecofeminist perspective of the American novelist, Ursula K. Le Guin (1929-2018), in her novel Always Coming Home. The novel is a futuristic science fiction which indicates the oppressions of both women and nature because it displays the woman's experiences in two dissimilar worlds of Kesh and Condor. Each world offers different culture, language, and lifestyle that steadfastly affect the personality of the heroine. The protagonist has three different names according to the environment in which she lives. The ecological consciousness of Kesh people leads to harmonious and calm life. In contrast, the patriarchal Condor looks at nature and women as a thing to be dominated. Throughout these two different cultures, Le Guin draws the attention of the reader to the world which is more suitable for the nonconformist heroine. This study uses ecofeminist approach that appeared as a reaction against the domination of both women and nature. Ecofeminism works for achieving equality between genders in order to protect nature and women through partnership. 


\section{Ursula K. Le Guin: Her Style and Her Vision}

Le Guin is a prominent American female writer who was born in 1929 in California. She is different from other women writers by her style of science fiction and fantasy. According to Rashley, "since the late1960s, Le Guin has challenged numerous conventions of science fiction in her novels, depicting characters who redefine our understanding of gender and race and creating plots with clear political subtexts" (2007, p.22). She uses mainly all the subjects of "sociology, social sciences, anthropology, feminist issues, and ecology". In her writings, she often handles the subjects of diverse cultures and worlds (Demir, 2011). Parallel to the characters that she has used, she attempts to create a new understanding of sexual identity.

Although the main characters in science fiction are generally male heroes, Le Guin challenges this ideology by bringing women heroines to the genre of science fiction (Demir, 2011; Rashley, 2007). As Lefanu states "Science fiction is popularly conceived as male territory, boys' own adventure stories with little to interest a female readership....but even then there were women writers, like C L Moore and Leigh Brackett" (1988, p.2). So she endeavors to establish "woman's tongue" in order to insist on the idea that what man is able to do, woman is also able to do. Basically, she believes in the idea of equality between genders in literature and in society. That is why she brings heroines to the science fiction genre (Demir, 2011).

Science fiction is primarily concerned with nature and it adopts the realist details from the real life of humanity. The works in this sort of literature are mostly narratives which describe the postulated futuristic societies including the creatures that exist in the two worlds and experiencing life in different planets. Robert further argues that "In other words, science fiction as a genre or division of literature distinguishes its fictional worlds to one degree or another from the world in which we actually live: a fiction of the imagination rather than observed reality, a fantastic literature" (2002, p.1).

Ursula K. Le Guin thinks that there is always a link between everything in the world involving "human and non-human, man and woman" because they are interrelated for continuing life. Concomitantly, she focuses on the problematic contemporary philosophies of both feminism and ecology. Her novel ACH is considered as a significant novel because it embeds the ideologies of ecology and feminism (Demir, 2011). Throughout ACH, Le Guin attempts to uncover what she previously worked for such as, woman's tongue, environmental issues, and feminist issues.

\section{The Conflict between Civilization and Nature}

In the "Introduction" to ACH Ursula K. Le Guin states that: "The people in this book might be going to have lived a long, long time from now in Northern California" (ACH, p. xi). Le Guin composes two constructing worlds or cultures that the heroine lives in. The novel depicts the changeable lifestyle of Stone Telling who is the heroine of the story who has experienced two different venues. Stone Telling lives with her mother from her birth day in a small town "Sinshan" in Kesh, but when she meets her father, she decides to go with him to Condor. Kesh and Condor are dissimilar communities, with totally different culture.

The novel is regarded as a utopian science fiction narrative because it is about the futuristic time and the perfect life of both women and nature in Kesh ( Fitting, 1987, p.19). For the protagonist, Kesh has been recognized as the first world where she opens her eyes. The core emblem of Kesh culture is the interrelatedness of everything in nature. The first world culture is free from gender inequalities which appreciates the non-human things. Mainly, Kesh culture is based on equalities between the two genders and equalities between human and nature as well. In contrast, Stone Telling's father is from Condor which is considered as the second world. Stone Telling starts to live in Condor when she grows young. Therefore, Condor is seen as the second world for the heroine.

The two cultures of Kesh and Condor are totally opposite to each other, especially in issues associated with women and nature. Condor culture is based on patriarchal system which completely rejects gender equalities. 
Nature and environmental issues are ignored there and as a male-dominated society, Condor culture always endeavors to suppress women and nature in order to serve the progress of civilization. The story of $\mathrm{ACH}$ is constructed upon Stone Telling's journey in the two different societies of Kesh and Condor and also her reaction to the injustices she experienced in Condor culture. By her journey, she faces so many struggles in her father's society because Condor culture ignores the issues of women and nature. Although she has faced various difficulties in her father's society, these difficulties turn to be the major factors behind the development of her personality. This novel is the manifestation of Stone Telling's personal alteration and her maturation in societies of Kesh and Condor. According to Murphy "this inner narrative is feminist bildungsroman detailing the experiences of a girl who chooses between her father's patriarchal culture and her mother's matrifocal one" (1995, p.28).

$\mathrm{ACH}$ is an excellent instance of ecofeminism because the heroine's experiences uncover the contradictions in the cultures of Kesh and Condor regarding ecology and feminism (Demir, 2011). Kesh, as the first world where Stone Telling has lived, provides two important issues including: harmony between nature and humans and harmony between the genders.

The first part of this section analyzes the important role of nature in $\mathrm{ACH}$. The novel begins in the birth place of Stone Telling where she lives with her mother and grandmother in Kesh community. In Kesh, the meanings of people's name are all associated with nature. So the protagonist's first name is North Owl, her mother is Willow, and her grandmother is Valiant. According to Kesh culture, home is the most important place for women and it certainly belongs to them. Women have all the right to let men stay with them or to leave. Basically, life in Kesh is completely peaceful and calm and all the houses have dissimilar names. "High Porch" is North Owl's house name. According to Demir (2011), the people of Kesh are matriarchal because daughters live with their mothers in the houses which are called "Nine Point". Kesh people live in a Valley which contains nine towns and all houses in the Valley have different names. The houses have been divided into five kinds which are wholly linked to nature and natural accidents as synchronically embed Obsidian, Blue Clay, Serpentine, Yellow Adobe, Red Adobe. Even the sky has been divided by Kesh society into four types involving Rain, Cloud, Wind, air. Thus, admiration for nature is widely seen in their attention to nature's rituals because all celebrations, parties, and dances are generally based on nature.

Indeed, the Kesh society has proved its loyalty to nature in their way of living by protecting nature from any action that could damage it. Nature has been observed as a friend to humanity rather than a place to dominate. Kesh's people strongly believe in the idea that if nature is treated properly, it could fulfill humanity's need for living peacefully. Before doing any activity related to nature, they endeavor to determine a serious plan not to harm nature. Therefore, technology and science are less used in Kesh because of their respect for nature. When Condor men came to build a bridge in a valley where Kesh people lived in, the people of Kesh stood against it. So, one of Ounmalin women raises her voice and says: "if a bridge at this place were appropriate, there would be one" (ACH, p.34). Sun Weaver as another woman expresses herself and argues that "this bridge would not be in the right place" (ACH, p.34). The people of the Valley discover that building a bridge is very harmful to nature and they insist on their opposition. That is because they think about the fate of the river and people who live alongside it. Thus, the way Kesh people react against building the bridge is quiet nonviolent and harmless "many people in Ounmalin refused to give anything to the Condor men, or speak to them, or look at them, and starting attending meetings of the Warrior Lodge" (ACH, p.36).

Definitely, technology and science are only used when necessary in Kesh culture because people mostly deal with nature rather than scientific productions. Under the title of civilization Condor men attempt to build a bridge in the Valley in order to civilize Kesh society. building this bridge in the Valley is to fulfill Condor men's needs and desire. Opposite to Kesh people, Condor men extremely depend on technology and science because they believe that nature is no more than an object that should 
be dominated and it exists for serving human needs.

Without any doubt, Kesh community rejects both systems of overpopulation and "overusing natural sources" (Demir, 2011). As a result of their awareness of nature, they do not accept anything which could hurt it. Essentially, Kesh people are so generous about what they have. As long as happiness, sadness, as well as wealth have been shared with all people in the Valley, the ownership will cease to be the privilege of a single individual, but to the whole society. They believe in helping each other in all situations because the Kesh culture is famous for its equality system in every field of life:

"the Kesh idea of property was so different from ours that any mention of it entails explanations. What one made, or gained, or owned, in the Valley, belonged to one; but one belonged to one's House, and house, and town, and people. Wealth consisted not in things but in act: the act of giving" (ACH, p.112).

Theater and art have specific roles in Kesh society, because they are very careful about education and art. Basically, they have diverse types of songs according to the ritual of seasons. They are also interested in dancing with the songs. Of course, the inspiring sources of songs, dances and activities totally belong to nature's occasions as well. According to them nature is unique and must be protected in order to embrace all humanity. Kesh people think that behind any earthy disaster there are humans and Man is considered as the major cause of the destruction and destroying nature. Therefore, any inappropriate disaster which happens to humans is because of their abuse of nature. According to Capra, the current instigations explain that the ecological deterioration has resulted from this "crisis of perception" in the individuals. The reason is that "crisis of perception" comes from the fact that people and their huge "social institutions" contribute to "the concepts and the values" and as well as systems of an out-of-date worldview, in which they are insufficient to deal with the problems such as overpopulation and globalization in the world (1987, p.19). Contemporary life is not free from the historical concepts which have a negative effect on the new generation's lifestyle:
"The people of valley did not conceive that such acts as they saw and felt much evidence of in their world- the permanent desolation of vast regions through release of radioactive or poisonous substances, the permanent genetic impairment from which they suffered most directly in the form of sterility, stillbirth, and congenital disease- had not been deliberate. In their view, human beings did not do things accidently. Accidents happened to people, but what people did they were responsible for. So these things human beings had done to the world must have been deliberate and conscious acts of evil, serving the purposes of wrong understanding, fear, and greed. The people who had done these things had done wrong mindfully. They had had their heads on wrong" (ACH, p.159).

In contrast, the other culture in $\mathrm{ACH}$ is Condor or Dayao. The lifestyle and system in Condor culture are completely opposite to Kesh culture. Through her father, Stone Telling's life combines with this society because her father is a Condor man. Principally, this patriarchal society regards women as slaves or servants of their desires. Women are even treated as inferior as nature because according to Condor men's system, no women can leave the house. But, Condor men can go freely to anywhere they wish. They spend their times on the roads in search for food and development for their society. The extreme usage of technologies is considered as a distinctive symbol of Condor community.

The core of Kesh culture is nature-based life. In Kesh society, everything including systems, organizations, foods, songs, dances and the names is absolutely nature-related. The evidence can be seen in one of the poems:

"come among the unsown grasses bearing richly, the oaks

Heavy with acorns, the sweet roots

in unplowed earth.

Come among the deer on the hill, the fish in the river, the quail in the meadows.

You can take them, you can eat them, Like you they are food.

They are with you, not for you (ACH,p.76). 
When North Owl with her father entered the boundary of Condor world, she got shocked by all those advancements which the Condors are well-known for. The narrator describes:

"I saw the towers of South City and the walls of black basalt, the wide streets at right angles, the splendor and array. I saw the magnificent bridge across the Dark River and the road that lay straight as a suntrack on water to the north, to the City. I saw the machines and engines of work and war they used, of most exact and elegant make, marvelous products of handmind. All I saw was great, and straight, and hard, and strong, and I saw it all in fear and admiration" (ACH,p.194).

Although she lacks the necessary information about the existence of those developments but, she feels amazed as she looks at them. Essentially, North Owl does not see such things in her previous world, the Kesh. The narrator states that "it seemed that copper wire was as common to them as string to us" (ACH, p.195).

In $\mathrm{ACH}$, Le Guin displays life in two different places, the City and the Valley. The City represents the Condor civilization, but the Valley represents the nature-related Kesh because Kesh people live in the Valley. Their life is simple and calm. In contrast, the Condor culture is heavily based-on technology and science in order to push the city forward (Otto, 2006, p.112). The progression of Condor culture is associated with the usage of high technologies which are the prime causes of nature degradation. All the technologies and scientific productions are regarded as man-made and therefore, "the City of Man" symbolizes the Condor society (ACH, p.153). Stewart writes:

"In the times of civilization men had really felt themselves as the masters of creation. Everything had been good or bad in relation to man. So you killed rattlesnakes. But now nature had become so overwhelming that any attempt at its control was merely outside anyone's circle of thought. You lived as part of it, not as its dominating power" (1949: p. 281).

Still, the Condor has been calculated as a civilized city because of their advanced technologies. They are always busy with finding new materials to dominate other societies and exploit nature for their wishes. The dependence on technology and science is a significant symbol of the Condor culture (Hanafy, n.d).

"metals and other raw materials needed for their physical plants and technical experimentation were mined by their robot extensions in poisoned areas or on the Moon and other planets; this exploitation seems to have been as careful as it was efficient"(ACH,p.150).

To a general extent, women and nature are interrelated in ecofeminism because they have some resemblances in the male-dominated society. Both nature and women are misused during the process of civilization.

\section{Oppression of Women and Nature Under Condor's Patriarchy}

Always Coming Home traces the heroine's experiences in two different cultures of Kesh and Condor. In the Kesh, women give different names to themselves according to the changes and situations of their life. According to the heroine's situations, she has three names. She took the first name "North Owl" when she was born and grew up as the Kesh daughter of a town woman "Willow"; her second name was "Ayatyu" when she was in Condor, and she names herself "Stone Telling" when she returns home. North Owl's father "Terter Abhao" was from the patriarchal Condor. She experiences the calm life in Kesh society because she has lived with her mother and her grandmother in one house and their culture is harmonious with nature.

After the arrival of Condor men, North Owl has realized the Condors' attitudes toward everything. Step by step, she is shocked by Condor culture and what is going on there, but her shock turns into struggles when she arrives at Condor world with her father's companionship. So, her father changes her name from North owl to "Ayatyu" which means "wellborn woman" or "woman born above others" in the Valley language (ACH, p.186). Basically she decides to leave Kesh in order to live with her father.

Indeed, the Condor society is indicated as a patriarchal society in which women and nature are determined as inferior to men. The Condor world is extremely notorious for its slavery system. The usage of names like "Dayao" or 
"One-People" is the major distinction of Condor people from others. They all serve and obey their leader who is just one man called "The Condor". Only some particular men who belong to specific families are called "True Condor". Concomitantly, the names of "tyon" or "farmer" are given to other men that are not related to those families and they are generally obliged to serve the True Condors. Even the women from those families must serve and obey Condor men. Thus they have been called "Condor Women". At the same time, the Condor Women can give orders to both tyon and hontik because they are slaves. The name "hontik" has been given to all other women who do not belong to those families and "foreigners and animals" as well (ACH, p.193).

Furthermore, Condor women and hontiks are not treated as humankind, but as animals. On their journey to the city of Condor where the house of Ayatyu's father is located, women start to speak in the cart together. Later on, Ayatyu discovers that the Condor men can never marry hontik because they regard them as animals. The woman of Tsaya Bele household states that: "there is no marriage between Man and animal" while she was explaining the process of marriage in the Condor (ACH, p.196). Condor men must only marry the daughters of Condor men who are called Condor women. As the narrator declares "the hontik, that is women and foreigners and animals, have nothing to do with one at all; they are purutik, unclean, dirt people. They were made by One to obey and serve the Sons" (ACH, p.200). The negative description "dirt" is given to hontik because they are raped by Condor men and farmers as well. Otherwise, the positive and prideful description "clean" is definitely given to Condor women due to "the matter of sexual jealousy" of Condor men. All the Condor men's attempts have served the idea of keeping their daughters and wives away from anyone and everything because they think that they will be raped by whoever they meet. Often their whole attention is on sexual desires because they believe that women existed only to fulfill men's desires (ACH, p.200). The Dayao describes that: "men fuck animals, but they don't bring the cubs home, they don't bring dirt persons into the house" (ACH, p.343).
The Dayao are always in search of fertile locations, so their life is not as stable as the Kesh people. The need for foods and new materials increases side by side with the quick growth of Condors population "the Dayao were very skilled artisian in metal and machinery, and excellent engineers" (ACH, p.349). The exploitation of nature goes up with the process of progression and overpopulation. For the Dayao, enlargement is crucial because they are warrior people and they are also in need of more places to do for their overpopulation. Inside, they treat each other according to their rules but outside spheres, they severely try to dominate other people. Conquering is the only relationship between the Dayao and other societies because the base of their ruling systems depends on domination and exploitation. Advanced technologies and also having the great military power would help them dominate other communities easily. The process of conquering has been done by force and violence (Demir,2011). The narrator describes that:

"the Condor people seem to have been unusually self-isolated; their form of communication with other peoples was through aggression, domination, exploitation, and enforced acculturation. In this respect they were at a distinct disadvantage among the introverted but cooperative peoples native to the region" $(\mathrm{ACH}$, p.379).

Not surprisingly, the patriarchal system of the Dayao pays no attention to nature because they think that it represents a place for limitless deteriorations. Even the children, women and slaves are regarded as inferior as nature. No women can read or write in Condor culture because reading and writing are considered as holy and women are dirty and they should not touch blessed things. As Ayatyu's father, Terter Abhao says "writing is sacred. Not for hontik. You don't need to write words" (ACH, p.189). The regulations of Condor heavily refuse to let women read or write any word because they are inferior to men. If any woman tries to practice it, the Dayao will punish her severely:

"when I was Ayatyu I had to forget writing and reading altogether. The Dayao will blind the eye or cut off the hand of a woman or a farmer who writes a single word. Only the True Condors may write or read, and of them I think only the 
ones called the One-Warriors, who officiate at the wakawa, learn how to write and read freely" (ACH, p.192).

The Condor men totally reject speaking with women in front of the Dayao. Even listening to women brings shame to Condor men. In the presence of the Condor men in the Kesh, Terter Abhao refuses to talk to women. As North Owl states "my father did not like to talk to women in front of Condor men" (ACH, p.34). Because when Ayatyu was in Kesh society, her name was North Owl. Although North Owl in Kesh culture is the same person but, Ayatyu's life in Condor culture is completely different from North Owl's life. The changeable circumstances in which she has lived, leave a deep imprint on the various personalities of North Owl, Ayatyu as well as Stone Telling. The narrator declares that "Ayatyu was becoming another person as Coming Home" (ACH, p.368).

Despite all these unfair situations facing women in Condor society, the Dayao has been recognized from other societies by its system of authority. Just only one person leads the whole people of Condor; he is called "The Condor". It can be said that it is a hundred percent dictatorial authority because he is the only one who can give orders to all including the True Condors, farmers, tyons, Condor women and hontiks. There is nothing for the good of the public because everything happens for One's desire. With this limitless authority, he can kill, dominate, corrupt and destroy everything. The Condor culture is a totalitarian one because the leader is responsible for everything:

"True Condor warriors were to be one thing only, reflections of One, setting themselves apart from all the rest of existence, washing it from their minds and souls, killing the world, so that they could remain perfectly pure. That is why my father was named kills. He was to live outside the world, killing it, to show the glory of One" (ACH, p.201).

But, Kesh culture is not totally dissimilar to that of the Condor. The people in Kesh believe in liberty and limitless lifestyles rather than being led by One. No one leads the Kesh culture because they do not accept any oppressive system to control them. Without having leaders, they prefer to have meetings in order to decide when they want to accept or reject an event.
They totally depend on public decisions rather than dictatorship. According to Demir (2011), even religion is regarded as an oppressive tool so, there is no specific religion in Kesh culture. Kesh people do not deal with any system of religion in order to continue because they think that depending on any system will lead to harnessing freedom. They like to live freely without any religions or oppressive systems. According to Demir (2011), for Kesh people, not religion but "the Valley life and thinking" are considered as sacred. Le Guin writes:

"I do not refer to the system of the nine houses as a religion or the heyimas as religious houses, despite the obvious and continuous relation of Valley living and thinking with the sacred. They had no god; they had no gods; they had no faith. What they appear to have had is a working metaphor. The idea that comes nearest the center of the vision is the house; the sign is the hinged spiral or heyiya-if; the word is the word of praise and change, the word at the center, heya" $(\mathrm{ACH}$, p.49).

For the heroine, Kesh society seems to be a peaceful world and this is reflected in her comfort and having full right to do whatever she likes such as participation in celebrations, writing and reading and so on. The Kesh people do not forget nature's protection in any activity that they do. Essentially, the lifestyle of North Owl's world is recognized by harmony with nature. In contrast, Condor looks so strange for her because she has never experienced those oppressions before. Women and nature have been considered as things to dominate and even inferior to men. Women have no right to read or write or leave her house under any circumstances. She spends seven years full of oppression and miserable situations in her second world, Condor. As a result, she could not stand those oppressions. Thus, she decides to escape from the Condor society because they do not let her leave freely. When she reached the Valley again, she felt free from everything which circled her in Condor culture. In brief, all the merits and demerits that she has experienced push her to maturation. For the last time, she alters her name to "Stone Telling". She has gone through various situations which affect her personality. Hence, with the change of the names, the personality also changes. 


\section{Ecofeminist Features in Always Coming Home}

$\mathrm{ACH}$ is the most recognizable novel which indicates the ecological consciousness of the Kesh and the patriarchal oppression of the Condor. According to Vakoch, this novel "articulates aspects of cultural ecofeminism" (2012, p.5). There is a strong interconnection between women and nature because both are obviously dominated by men. That is why it can serve the ecofeminist perspective. Murphy argues that "the novel that balances and integrates ecology and feminism more evenly and successfully than any other I have ever read is Ursula K. Le Guin's Always Coming Home (1985)" (1996, p.238).

The successive theme, the connection between nature and women starts from the beginning of the novel when the child's names are mainly linked with nature. In the Kesh, the names often come from the birds. She takes her first name "North Owl" from an owl that comes every night to the oak tree in her mother's garden to sing its song, the month before she was born. Furthermore, her last name also comes from nature, but this time not from birds. She transforms her name to "Stone Telling" when she escapes from the Condor and returns home. The self-identification of "stone" relates to her character after experiencing disparate situations and cultures:

"Stone Telling is my last name. It has come to me of my own choosing, because I have a story to tell of where I went when I was young; but now I go nowhere, sitting like a stone in this place, in this ground, in this valley. I have come where I was going" (ACH, p.7).

The interrelatedness of women and nature has been mostly signified as a sign of ecofeminist approach because the fate of human is surely linked with the earth. The best indication of this interconnection has been determined throughout the names which amazingly link the inanimate and animate things (Hanafy, n.d). There are three main reasons why she picks the name "Stone Telling". Using the word "stone" asserts the interconnection between nature and women in the Kesh society. By choosing the word "Stone" she combines her personality with nature again. But dissimilar to the first name, she feels that she is a part of nature when she describes:

"I began to feel the Valley behind me like a body, my own body. My feet were the seachannels of the River, the organs and passages of my body were the places and streams and my bones the rocks and my head was the Mountain. That was my all my body" (ACH, p.189).

On the other side, as it is a fact that "stone" is a part of nature, but it does not tell anything. She purposely alters her name to "Stone Telling" because she endeavors to display what she endured in her second world that made stone speak. Using the word "stone" can also mean an emotionless and motionless object. So after her bitter experience, she has turned into a motionless and emotionless thing. According to Otto, ACH envisages the social and philosophical alterations that parallel the closeness to ecofeminist project; reforming the value of "Earth-based spiritualities" and progressing the spiritual connection between human and nature, despite the cultural factors which prevent the progress from occurring (2006, p.103).

Indeed, the agricultural Kesh community is interested in nature and animals. Most of the people are farmers because they want to deal with nature more than anything else. For them, nature is the source of life. In contrast, Condor culture is an industrial one that does not have so much information about nature, earth, hunting, and farming. In Condor culture, nature represents nothing more than food or materials because the usage of nature is limitless in their industry. From their perspective, agricultural works are inferior and quite inappropriate to the Condor men (Demir, 2011). Once Abhao came to see Willow and his daughter in the Kesh, he expressed his reaction when Willow asked him to share work in the garden. He strongly rejected working in the garden because he thinks that farming is an inappropriate job for the Condor men:

"Blue clay, red clay, what does it matter!' he said. 'Any fool can dig black mud!' My mother sat spinning awhile and said at last, 'That's crazy talk'.

She laughed again. 'If any fool can, why can't you, my dear?'

My father said stiffly, 'I am not a tyon' 
'What is that?'

'A man who digs dirt'

'A farmer?'

'I am not a farmer, Willow, I am a commander of three hundred, in charge of an army, I am There are things a man can do and cannot do. Surely you understand that!" (ACH, p.32)

Concomitantly, the inequalities between men and women enter the field of work especially when the work is classified according to genders. The patriarchal culture of Condor does not allow women to have any roles in the society. They oblige women to stay at home and serve the Condor men and children. Just women and slaves are chosen to endure home responsibilities. Even practicing education through writing or reading is not allowed to women. The Condor men always spend their lives outside their house because they are in charge of conquering other peoples and places (Demir, 2011).

The "civilized life" of Condor is divided into two types of cities; "the City of Mind" and "the City of Man". The City of Mind or "Yaivkach" receives more attention because eleven thousands of these kinds of cities existed all over the world. The City of Mind refers to those cities which are associated to each other by exchanging information. They attempt to gather information endlessly in all the time. Through science and technology, they progress in order to control nature and other societies. Using science and technology are the easier way of domination. Except for the information and data, the City of Mind has not any relation with the life of humas whatsoever. Even their relation with animals and humans are restricted $(\mathrm{ACH}$, p.149-150). The narrator writes "endless knowledge was there, if one could get at it; for the goal of the Mind was to become a total mental model or replica of the Universe" $(\mathrm{ACH}$, p.151). That is why the City of Mind symbolizes the power of Condor society. Yaivkach has the capacity of saving every information-items and data-items limitlessly. The prime cause behind their existence is no more than collecting data and information. The City of Mind is definitely man-made because every technology and machine are constructed by Man. (Demir, 2011).

Apparently, the idea of evolution is accepted strongly by the City of Mind and the people have been seen as "markers" because only Man can make evolution. Without any doubt, Man is a superior species. Philosophy, science, machine, and technology represent the power of Man in creating such things (Demir,2011). According to the narrator:

"If the people of the Valley took the City of Mind for granted as a 'natural thing' as we would say, the City itself seemed to recognise its ancient origins in human artifacts by the TOK word for the human species and its members, which translates as 'markers'. And the City's maintenance of the exchanges for human use seems to show that it recognised humankind as related to itself by the capacity for mentation, language, and mathematics...." (ACH, p.152).

It is evident that the Condor men practise authority upon everything in their world and other worlds. The City of Mind can have a strong influence on displaying the Condor as a powerful society in order to dominate other societies. That is why all other societies feel afraid of the power of the Condors because they are aware of the Condor's technology. Owning high technology helps them gain all the information world-wide in order to dominate and exploit nature as they desire. With the help of progressive war techniques which they have, it is so easy for the Condors to bring other cultures under their control. But, the authority and power may bring non-confidence and fear to other societies as the Condor people are fearful and hateful (Demir, 2011). So, science and technology can provide power to any community to be more powerful than others.

In Contrast, the City of Man or "Tavkach" refers to those cities where the women and slaves are dominated by the patriarchal Condor people. Through their system of patriarchy, they can control women and nature in order to prove their superiority. There is no significant role for women and nature in the Condor culture because they are regarded as inferior species to Condor men. Women are responsible only for serving men and producing children because they could not go outside their house (Demir, 2011). As the narrator writes "Dayao women lived under siege all their lives" (ACH, p.195). Women are never allowed to experience life outside their house and even they could not attend or participate in any festivals or come close to the vestibule to 
hear the songs from the festivals too. Also the narrator says: "girls and women were taught nothing but the skills of the household....Women have no part in the intellectual life of the Dayao; they are kept in, but left out. It was not men there, but women, who told me that women have no souls" $(\mathrm{ACH}$, p.200). According to Reed, the division of the work between the genders are explained as "misleading formula" because men are free in choosing works of "warriors" and they are "providing the necessities of society". In contrast, women merely stay at home and they are responsible for cooking, raising children, doing house works or everything related to home (2017, p.53).

Both "civilized" Condor cities "the City of Mind" and "the City of Man" are regarded as the prime cause behind the deterioration of nature as well as the oppression of women. It is the man who creates the system of patriarchy and technology. Mies and Shiva suggest that "science's whole paradigm is characteristically patriarchal, anti-nature and colonial and aims to dispossess women of their generative capacity as it does the productive capacities of nature". In the Condor society, every female endures more than what is imaginable. (2014, p.16).

When the protagonist of $\mathrm{ACH}$ starts to live with the Condors, the rules of Condor society will be applied to her definitely. Her father obliges her to wear scarves in order to hide her face from other men because men are the only rulers of the society and they can ask whatever they wish from women and nature. The narrator mentions that "Put it on! He said. It was not just order-shouting, but nervous anger; he was anxious. Keep it on, over your face..." $(\mathrm{ACH}$, p.198).

Both nature and women have been viewed as belongings or things to be dominated by males. The narrator states that "A Dayao man belongs to himself. He thinks everything else belongs to him, women, animals, things, the world" $(\mathrm{ACH}$, p.367). Man gains the opportunity of being master for controlling his environment (McGowan, 2017). They behave with women as if they were soulless and not human beings as they are. Also they feel the ownership of women regarding the control of her lifestyle in clothes, speech, and so on. When Ayatyu decides to escape from the Condor and to return to her birth place, Terter Abhao firstly rejects the idea and says: "Listen, Ayatyu, since you chose to come here it can't be undone. If you run away from your husband, you put me into shame and disgrace. You belong to the Retforoks now. Better stay with them. You are well out of my house" (ACH, p.347). Generally, the Condors do not let women discover their identity and know their personality throughout their roles in life. Women cannot depend on themselves because they are considered as a property to men. Ayatyu has a conversation with the first wife of her husband about Dayat when she said "you belong to Dayat, don't you see? You belong to him, I belong to him, that's how it is" (ACH, p.346).

Likewise, nature is treated in the same way women are. The Condor men consider themselves as the owner of every land. By their high war techniques and dangerous military power they dominate whatever space they desire. Waging war is the only way to own the land of other societies. That is why nature is no more than a thing which completely belongs to them. A good evidence of this is when Ayatyu and her father were on the road to Condor, Terter Abhao stated that:

"I spent ten years of my life winning the land around that mountain for the Condor, and now it's all to do over. He used the word zarirt, which I had learned playing long-dice with the soldiers; it means to win at gambling, like our word dumi. I could not imagine what he meant, how he had won an enormous piece of the world like that, or who he had won it from, or what use it was to him" (ACH, p.191).

In this novel, women and nature are oppressed most brutally alike. For the Kesh people, living in the Condor society means "living outside the world" because it is the exact outcome of the masculine philosophy. The idea of oppression is the central theme in the patriarchal Condor and the narrator continues reporting her experience in it. So, Le Guin's attraction to ecofeminism has been confirmed throughout the novel (Otto, 2006, p.116). The Condor people are mostly criminals as the narrator confirms "They killed and burned men and children and kept women to be fucked by Dayao men. They panned the women with the cattle" (ACH, p.193-194). A part from 
themselves, they do not have any respect for other societies and people. The advanced technology and military power are crucial factors for their domineering authority.

Furthermore, Ayatyu's oppression continue when she gets married to the Condor man "Retforok Dayat", and she becomes his second wife. Condor men often take a second wife because the Condor "believed that animals and women were contemptible and unimportant" (ACH, p.345). The women are responsible for taking care of their husbands and children. The narrator declares women's position according to Condors: "Condor's wives were expected to have babies continuously, since that is what One made women for" (ACH, p.345). Ayatyu does not see any of these situations before in the Kesh, so she does not know how to deal with it. Although she becomes pregnant twice, she aborts the first one because she was raped in spite of herself. A child of rape is refused by Ayatyu while other Condor's daughter accepts it.

Ayatyu can't bear those oppressions and therefore, she decides to return to the Valley. Spending seven years "outside the world" as the Kesh people mention, leave a great effect on her whole life (ACH, p.153). She despises the life in the Condor because she has never seen such unfairness and injustice in the Kesh. She does not understand why women must obey men in the Condor, and she feels displeased with their commands. The narrator describes that: "There is no way that men could make women into slaves and dependents if the women did not choose to be so. I had hated the Dayao men for always giving orders, but the women were more hateful for taking them" (ACH, p.355).

Before coming to the Condor, even in her first world Kesh, the protagonist was a bit dissatisfied in staying with her mother and grandmother. In addition, Ayatyu in the Kesh was North Owl. When she was only eight years, she felt incomplete because her father was not living with them in Kesh, so she has been addressed as "half-person" (ACH, p.19). She even describes her family in a sentence which is, "I had only half a family" (ACH, p.181). According to Otto (2006), since her father's first meeting after so many years, she has felt a different sense which is completeness.
Unfortunately, her happiness did not continue when soon she realized that her father's coming was not for the sake of his family, but for building a bridge. It is even possible to say that her illusions of familial completeness contradicted with the intrinsic ecological issues of the Kesh culture. The narrator stated that: "He was home, he was here, our family was whole; now everything was as it should be, balanced, complete; and so it would not change" $(\mathrm{ACH}$, p.30). This situation serves as a prominent subject of ecofeminist approach. One of the most important subjects in ecofeminism is partnership in every field of life. Basically, North Owl wanted to have a normal life with her father and mother, but her father could not stay with them because he was a commander of the Condor army and he must take orders from One.

In $\mathrm{ACH}$ women and nature are oppressed, by the Condor culture which is the outcome of the patriarchal system. Advanced machinery and technology are particularly men's job in the Condor and they are the main cause behind exploiting nature in Condor as they depend on technology in every action. So, all the kinds of weapons as a special inspiration of the Dayao have been made limitlessly to be used in the wars (Otto, 2006). This is quite clear when Ayatyu declares that the Dayao have "Great Weapons" (ACH, p.349).

Indeed, Le Guin explains her affinity to ecofeminism through Ayatyu's speeches and feelings in the novel. She thought about the Valley when she saw "Destroyer", a huge tank which pushes everything in front of it. She describes it in full details as a huge blind tank which ruins everything and leads the army. The name has been purposely given to it because it suits the action totally. Doubtlessly, the Dayao men are the creators of such a destructive thing that definitely destroys nature without mercy $(\mathrm{ACH}$, p.350). Ayatyu has never seen such things in her first world, Kesh. Physically she is in the Condor, but spiritually she is with the Kesh. The horrible shape raises her fear about the intrinsic nature of the Valley because she is ecologically conscious. By looking at the Destoyer, she immediately goes back to the Valley by using her imagination when she states: "imagining the Destroyer pushing against the oak trees named Gairga in Sinshan, pushing 
them over, pushing against High Porch House, pushing it's wall in, pushing against the roof of the Blue Clay heyimas, pushing the roof in. I imagined its metal treads, caked with adobe, crushing cornstalks and cattle and children into the dirt, grinding them as millstones grind" (ACH, p.350).

With the help of her father, Ayatyu and her daughter Ekwerkwe and her servant Esiryn escape from the Condor and reach the Kesh. After so many difficulties which she faced in the Condor, she finally returned to her first world or birth place. She could not endure more than what she suffered so she chooses to leave her second world, the Condor: "I had no more heart to be a woman of the Codor or to follow their way. I was living among people who were going the wrong way" (ACH, p.353).

Ayatyu was completely sure that there is no future for such a kind of world. Women mostly think about future, so Ayatyu could not remove the future picture of Condor's exploitation of nature from her mind. McGowan writes that "I firmly believe that the women can look to the future with certain knowledge that theirs will be a glorious position of dignity and human worth" (2017, p.129).

She has done something that nobody else can do in the Condor. No women have enough bravery to leave Condor because if they are caught they will be punished. The Dayao women cannot imagine their life without men "To Dayao women outside the walls of her father's or her husband's house all men are dangerous, because to Dayao men all women unprotected by a man are victims; they call them not women or people, but cunts" (ACH, p.360).

In fact, this does not mean that the Dayao women do not wish a better life. They are always talking about it, but they are frightened to move because most of them spend all their lives in the houses of the Condor city and do not have any idea of the other places (ACH, p.352). It is possible that traditionand culture oblige women to do things against their wills. Tradition makes women understand that they do not have the ability to change the situation. Finally, Ayatyu decides to react against her second world by running away from its culture. According to Demir (2011), she is aware of the deteriorations that could happen to the Condor because of their ignorance of nature. The society of Condor is destroyed day after day because of its overpopulation, lack of food, and mistreatment of women and nature. Without any doubt, Condor's system of domination which is based on abusing nature and oppressing women will lead to its own destruction. The narrator says that, "Destruction destroys itself" (ACH, p.380). Women stay as they are, but nature becomes tired of giving and finally will be deteriorated.

\section{Conclusion}

Always Coming Home includes both major themes of ecofeminism which are feminism and ecology. The ecological consciousness and equality between genders are widely appreciated by the Kesh people. The lifestyle of matriarchal Kesh is a perfect example of what ecofeminism suggests like: refusing the domination of nature and women. The Kesh people are aware of nature, so they do not use any technology or machines lest they harm nature. For the Condors, neither women nor nature are given any attention. Nature has been misused to serve their process of civilization, and women have been dominated to prove their authority. Generally, both nature and women are dominated by the male society of Condor. They are always in search of metals and natural resources to create advanced technology. They do not know that the system of patriarchy and deterioration of nature will finally lead to the total destruction of the Condor world. The Condor's domination and deterioration are the main subjects that ecofeminists work to solve. Ecofeminists suggest that through the partnership of both genders not only women, but nature also can be protected in the future. Ecofeminism connects man's oppression of women and nature together to reveal that there is no progress without the equality between genders and there is no future without due respect to nature.

\section{References}

1. Capra, F. (1987). "Deep ecology: A New Paradigm”. Earth Island Journal. 2(4), pp.1925 
2. Demir, S. (2011). Ecofeminist Themes in American Women's Novels. (Master Thesis: Dokuz Eylul University)

3. Fitting, P. (1987). The Decline of the Feminist Utopian Novel. Border/Lines. 7(8), pp.17-19

4. Hanafy, I.A. (n.d). "Ecofeminism Across Cultures in Le Guin's Always Coming Home". Review of Always Coming Home, by Ursula K. Le Guin. Accessed on March 15, 2018. https://www.academia.edu/19305809/ECOFE MINISM_ACROSS_CULTURES

5. Lefanu, S. (1988). In the Chinks of the World Machine: Feminism and Science Fiction. London: Women's Press

6. Le Guin, U.K. (1985). Always Coming Home. New York: Harper\& Row Publisher

7. McGowan, M. (2017). Cosmetics, Fashions and the Exploitation of Women. New York: Pathfinder Press

8. Murphy, P.D. (1995). Literature, Nature, and Other Ecofeminist Critiques. New York: State University of New York
9. (1996). "Ground, Pivot, Motion." Ecological Feminist Philosophies. Karen J. Warren. (ed), Bloomington: Indiana University Press.

10. Otto, E. (2006). Science Fiction and the Ecological Conscience. (Doctoral dissertation: University of Florida)

11. Rashley, L.H. (2007). "Revisioning Gender: Inventing Women in Ursula K. Le Guin's Non-fiction" Biography. 30 (1),pp.22-47

12. Reed, E. (2017). Problems of Women's Liberation. New York: Pathfinder Press

13. Robert, A. (2002). Science Fiction. London: Routledge ,Taylor \& Francis e-Library

14. Shiva, V. and Mies, M. (2014). Ecofeminism. London: Zed Books Ltd

15. Stewart, G. R. (1949) Earth Abides. New York: Fawcett

16. Vakoch, D.A. (ed), (2012). Feminist Ecocriticism: Environment, Women, and Literature. Lanham: Lexington Books. 